\title{
Are the littoral zone conditions suitable for tropical planktonic microcrustaceans?
}

\author{
Bruno Barretto de Souza ${ }^{1 *}$, Marlene Sofia Arcifa $^{1}$, Tânia Cristina dos Santos Ferreira ${ }^{1}$, \\ Lúcia Helena Sampaio da Silva ${ }^{2}$, Claudia Fileto ${ }^{3}$ and Andrés Ricardo Domingos ${ }^{1}$ \\ 1 Departamento de Biologia, Universidade de São Paulo, Avenida Bandeirantes, 3900, 14040-901 Ribeirão Preto, Brazil \\ 2 Departamento de Botânica, Museu Nacional, Universidade Federal do Rio de Janeiro, Quinta da Boa Vista, $20940-040$ \\ Rio de Janeiro, Brazil \\ 3 Núcleo de Estudos em Ecossistemas Aquáticos (NEEA), Centro de Recursos Hídricos e Ecologia Aplicada (CRHEA), \\ Universidade de São Paulo, Rodovia Domingos Innocentini, km 13, Caixa Postal 292, 13560-970 São Carlos, Brazil
}

Received 9 March 2017; Accepted 29 May 2017

\begin{abstract}
The occupation of the littoral and limnetic zones by planktonic species has led to questions about whether littoral macrophytes would be a suitable habitat or refuge. These questions guided our field and laboratory studies on the spatial occupation and the food suitability for microcrustaceans of a shallow tropical lake. Replicated zooplankton samples were collected over 18 days, at intervals of 3 days, at three zones (the middle and edge of the stands of the emergent macrophyte, Ludwigia sp., and the limnetic zone). Some species, such as the cladocerans Diaphanosoma birgei and Daphnia ambigua, showed preference for the littoral zone and the limnetic zone, respectively. Copepodites, and adult copepods Thermocyclops decipiens and Tropocyclops prasinus meridionalis are mainly limnetic dwellers. The size of the cladocerans Ceriodaphnia richardi and Daphnia gessneri did not differ between the zones, nor did the clutch size of the former species; smaller individuals of D. ambigua were found within macrophyte stands. In laboratory experiments, the seston of the three zones did not negatively affect the development of the cladocerans C. richardi and D. birgei. On the contrary, the seston of the middle of the macrophyte stands promoted better growth rates of both cladocerans and some of the life table parameters of $D$. birgei than the seston of the other two zones. Food quantity and quality are not negative factors to microcrustaceans in the littoral and limnetic zones. The preference or indifference of microcrustaceans to habitats may be part of their adaptive strategies regarding other factors, including predation.
\end{abstract}

Key words: Seston quality and quantity / life table / spatial distribution / macrophytes / limnetic zone

\section{Introduction}

The concept of true zooplankton may be controversial because of the difficulty in separating littoral and pelagic species (Walseng et al., 2006). The occupation of the littoral and limnetic zones by planktonic species has led to questions about whether littoral macrophytes would be habitat or refuge.

The diel horizontal migration (DHM) of microcrustaceans for escaping from limnetic predators (Burks et al., 2002) may lead organisms to unsuitable lake areas regarding food and littoral predators. In addition to hosting other predators (Wojtal et al., 2007; González Sagrario et al., 2009; Domingos and Arcifa, 2016, 2017),

*Corresponding author: brunobs@usp.br the food quality in the littoral zone may be questionable for planktonic organisms. The quantity and quality of seston are not well known in the littoral zone and have been considered inferior to the limnetic zone (Smiley and Tessier, 1998) or as having similar characteristics (Booker and Cheruvelil, 2011).

Phytoplankton, the basic food of planktonic herbivores, may have their growth impaired by dense macrophyte stands (Gopal and Goel, 1993; Søndergaard and Moss, 1998) due to shading (Mulderij et al., 2007), competition for nutrients (Carpenter and Lodge, 1986), sedimentation of non-floating algae (Horppila and Nurminen, 2005) and allelopathy (Mulderij et al., 2005; Zhang et al., 2015).

Limited food supply negatively influences the individual growth and parameters of the life table of cladocerans 
(Sterner et al., 1993). However, the zooplankton ability to use non-algal food, such as bacteria and detritus (Hessen et al., 1990; Hart et al., 2000), might enable them to thrive in habitats with vegetation (Smiley and Tessier, 1998). Besides food quality, inorganic suspended matter, often more abundant in littoral zones, may negatively influence intake rates by cladocerans (Kirk, 1991; Bozelli, 1998) and population growth rates, depending on the particle size, due to interference with the food collection mechanism (Kirk, 1991; Kirk and Gilbert, 1992).

Lake Monte Alegre was chosen as a case study because there is a large amount of data, including 33 papers published over 30 years of studies that may support the approach used here. The growth and reproduction of cladocerans in Lake Monte Alegre can be affected by the quantity and quality of food (Fileto et al., 2004), especially in the cool season (Ferrão-Filho et al., 2003, 2005), giving support to the hypothesis that food is a seasonally important biotic factor (Arcifa et al., 1992). In several studies conducted in the lake, cladocerans were more sensitive to the morphometric characteristics of the phytoplankton (Fileto et al., 2004) than limitation of algae by mineral content (Fileto et al., 2007) or by fatty acids (Ferrão-Filho and Arcifa, 2006). However, studies have focused on the limnetic zone, and the sestonic food quality in other lake areas, such as the littoral zone, including the middle and the edge of the macrophyte stands, is still unknown. Therefore, the search for shelter from limnetic predators would expose the organisms to a less favourable habitat for their development if food in the littoral zone was less suitable.

The purpose of this study was to evaluate whether planktonic microcrustaceans temporarily occupy the littoral zone of the lake in the short term, or if there is preference for the littoral and limnetic habitats. To elucidate this point, we carried out a short-term study encompassing three zones (the littoral, the middle and the edge of macrophyte stands, and the limnetic zone). Seston characteristics, physical and chemical factors and morphometric and reproductive aspects of cladocerans were also evaluated. Furthermore, we assessed experimentally in the laboratory whether the seston quantity and quality at the three zones influence population growth and life table parameters as crucial factors for species survival in the habitats.

Little is known about the offset between the escape from limnetic predators and adverse littoral conditions for planktonic prey. This study adds new knowledge in addressing the dietary, physical and chemical conditions for planktonic microcrustaceans in areas with and without macrophytes and the reproductive and population growth performance of two species of cladocerans used here as model-species.

The issues addressed in this paper are: (I) the distribution of planktonic microcrustaceans, chaoborid larvae and mites, in the littoral and limnetic habitats, respectively with macrophytes (middle and edge of the stands) and without macrophytes, in the short-term with frequent sampling; (II) the physical and chemical conditions as a barrier for the displacement of the organisms to the three zones; (III) whether the quantity and quality of seston differ in the littoral and limnetic zone and the effect on the reproductive performance and population growth rate of cladocerans; (IV) the advantages for planktonic microcrustaceans to occupy the littoral zone for avoiding limnetic predators, mostly chaoborids and mites; and (V) microcrustaceans that prefer the limnetic zone are subjected to higher predation by invertebrates, the main predators in the lake, but inhabit a zone more suitable for planktonic species regarding hydrodynamics and vertical displacements.

\section{Material and methods}

\section{The lake}

Lake Monte Alegre, $\left(21^{\circ} 10^{\prime} 04^{\prime \prime} \mathrm{S}, 47^{\circ} 51^{\prime} 28^{\prime \prime} \mathrm{W}\right)$ is located in Ribeirão Preto, São Paulo, Brazil, at an altitude of $500 \mathrm{~m}$ a.s.l. The lake resulted from damming, in 1942, of Laureano Creek, which belongs to the Pardo River Basin. The dam gates are not manipulated, the outlet is superficial and the retention time ( $\sim 45$ days) is relatively high for its dimensions, thus the reservoir functions similarly to a lake. The lake dimensions are: area 7 ha, maximum and average depths 5 and $2.9 \mathrm{~m}$, respectively. The region has two marked seasons: cool-dry (May-September) and warm-wet (October-April). The lake is eutrophic and discontinuous polymictic and, consequently, can stratify for longer periods during the warm season, leading to oxygen depletion in the deeper layers (Arcifa et al., 1990). The macrophytes, mostly the rooted-emergent species Ludwigia sp., are distributed in narrow stands, with a maximum width of about $4 \mathrm{~m}$ and occupying a portion of the southwestern shore of the lake.

The main invertebrate predators of microcrustaceans, in the limnetic zone, are larvae of Chaoborus brasiliensis and the water mite Krendowskia sp. (Arcifa, 2000; Cassano et al., 2002). Notonectids and gerrids can also consume microcrustaceans and are mostly distributed in the littoral zone (Domingos and Arcifa, 2016, 2017).

Zooplankton represents only $2 \%$ of the dietary items of the fish fauna (Arcifa and Meschiatti, 1993), and the only planktivorous fish is the adult of the exotic cichlid Tilapia rendalli, which is a pump filter feeder, feeding mainly on phytoplankton (Arcifa and Meschiatti, 1996). The fish fauna of the lake is composed of nine species of small- and medium-sized cichlids and characiforms, mostly distributed within the macrophyte stands (Meschiatti and Arcifa, 2002).

\section{Short-term study in the lake}

Zooplankton sampling was carried out from August 15 to September 2, 2013, over 18 days at intervals of 3 days, covering a period close to an average life cycle of local cladocerans, based on Fileto et al. (2004). Samples were 
collected at the littoral zone, in the middle of stands of Ludwigia sp. (M) at $0.5 \mathrm{~m}$, at the edge of the macrophyte stands (E) at $0.5 \mathrm{~m}$, and integrating the water column of the limnetic zone ( $\mathrm{L}, 4 \mathrm{~m}$ deep). Three replicates $(150 \mathrm{~L}$ each) were collected in three transects separated by $10 \mathrm{~m}$, with a pump (ITT Jabsco, Costa Mesa, CA, USA, mod. 34600-000), which releases 30 L.min ${ }^{-1}$. Sampling was conducted carefully to prevent contamination of the organisms in the zones, by using three hoses for the pump, one for each zone, the net being washed before each sampling. The water was filtered through a $58 \mu \mathrm{m}$-meshed plankton net and fixed with $4 \%$ formaldehyde after sugar addition. Counts were made in several $1 \mathrm{~mL}$ subsamples at a stereomicroscope on a gridded Petri dish, maintaining a maximum coefficient of variation of 0.20 among them. Chaoborus larvae and mites were counted in the total sample.

The environmental factors analysed were temperature and dissolved oxygen (Yellow Springs Inc., OH, USA, model 95), electrical conductivity, at $25^{\circ} \mathrm{C}$ (YSI, model 30), $\mathrm{pH}$ (YSI, model 60), turbidity (Turbidimeter HACH, model 2100p, Loveland, CO, USA) and chlorophyll- $a$ (Jeffrey and Humphrey, 1975). Reproduction of microcrustaceans was evaluated by counting eggs carried by the largest females, at least in 10 individuals per species and sample, which were also measured. The algal carbon was calculated based on the chlorophyll concentration, assuming that chlorophyll is $1.25 \%$ of the algae dry weight, within the limits reported by Reynolds (1984), and carbon is $50 \%$ of the algae dry weight.

\section{Experiments with seston from the three lake zones}

\section{Alga and cladoceran culture}

Cohorts of cladocerans originated from a single ovigerous female, collected in the lake and kept for generations in the laboratory, ensuring that all replicates were clones. The animals were cultured in $600 \mathrm{~mL}$-bottles with filtered lake water in glass fibre filter Millipore AP20, plus $1 \mathrm{mg} \mathrm{C.L}{ }^{-1}$ of the chlorophycean Desmodesmus spinosus (former Scenedesmus spinosus). The bottles were placed on a plankton wheel (turning 1 min every $5 \mathrm{~min}$ ) in the laboratory, with temperature $23-24^{\circ} \mathrm{C}$ and photoperiod 12:12 $\mathrm{h}$ and dim light. The temperature was the annual mean of the water column of the lake.

The chlorophycean was cultured in MBL medium (Stemberger, 1981) in an environmental chamber (FANEM, SP, Brazil, model $347 \mathrm{CDG}$ ), at $23^{\circ} \mathrm{C}$ and photoperiod 12:12 h.

\section{Experiments}

Two experiments were carried out: experiment I: with the medium-sized $(0.61 \mathrm{~mm})$ cladoceran Ceriodaphnia richardi, during the period $12 / \mathrm{II}-8 / \mathrm{III} / 2014$; experiment II: with the medium-sized $(0.62 \mathrm{~mm})$ cladoceran Diaphanosoma birgei, during the period 5-24/VII/2014.
The two species for the experiments were chosen based on their spatial distribution in the lake found during the survey of 18 days in this study. C. richardi was chosen because it was able to inhabit the three zones and $D$. birgei for its preference for the littoral zone (middle and edge of macrophytes). The objective was to test how seston would affect species with different spatial distribution, in relation to the littoral (middle and edge of macrophytes) and the limnetic zone.

Ten neonates were used for each treatment, individually placed in $23 \mathrm{~mL}$-glass vials, which were attached to the plankton wheel. The treatments were (10 replicates each): (a) seston from the middle of the macrophyte stand, (b) seston from the edge of the macrophyte stand, (c) seston from the limnetic zone and only in experiment II, (d) filtered lake water $+1 \mathrm{mg} \mathrm{C} . \mathrm{L}^{-1}$ of the alga $D$. spinosus. The vials remained on the wheel, at a room temperature of $23-24{ }^{\circ} \mathrm{C}$, photoperiod of $12: 12 \mathrm{~h}$ and dim light. The attempt to maintain a treatment with the chlorophycean in experiment I was unexpectedly unsuccessful, because the individuals died before the first reproduction. The seston for the treatments was collected with a Ruttner bottle at each zone of the lake and the water was filtered through a $140 \mu \mathrm{m}$-meshed net to prevent large zooplankton from entering the vials. The water was renewed daily to maintain the food quality and concentration, when the number of survivors and neonates were counted. Life table parameters, such as age and size of females at first reproduction, mean number of clutches, total neonates produced per female, mean fecundity, maximum neonates per clutch, generation time $(G)$ and intrinsic growth rate $(r)$ were evaluated during the experiments, following Gotelli (2009).

\section{Phytoplankton, suspended matter and abiotic factors}

During the experiments, seston characteristics were analysed at the three zones, in water samples collected at the beginning, middle and end of the experiments. The phytoplankton biomass was evaluated by converting chlorophyll- $a$ into carbon as aforementioned. The phytoplankton was counted in sedimented samples under a Zeiss inverted microscope, according to Utermöhl (1958), in random fields (Uehlinger, 1964). The amount of inorganic and organic suspended matter was measured according to Teixeira and Kutner (1962). Temperature and dissolved oxygen (YSI, model 95), pH (YSI, model 60) and turbidity $(\mathrm{HACH}$, mod. $2100 \mathrm{p})$ were measured at the three lake zones.

\section{Statistical analyses}

According to premises of normality and homoscedasticity reached by the data, one-way analysis of variance (ANOVA) with a post hoc Tukey test was applied for statistical analyses of algal carbon, body size and intrinsic growth rate $(r)$, while a Kruskal-Wallis test was applied for physical and chemical factors, density and population parameters, calculated from life-table analysis. 
The densities of the microcrustaceans were subjected to multivariate exploratory analysis using the ordination method based on McCune et al. (2002). A detrended correspondence analysis (DCA) with Multi-Response Permutation Procedures (MRPP) was applied. Analyses were performed using STATISTICA software 8.0-StatSoft and PC-ORD 5. The level of significance was $P<0.05$.

\section{Results}

\section{Short-term study in the lake}

\section{Physical, chemical and biological factors}

Due to the low variation of physical and chemical factors during the sampling period, only the maximum and minimum values found at each zone are presented (Table 1). Low concentration of dissolved oxygen (DO) was recorded at the bottom of the limnetic zone (L); in the middle (M) and edge (E) of the macrophytes, DO concentrations remained high during the period. The temperature values indicate that the lake was not clearly stratified during the sampling period. DO concentrations were significantly lower in $\mathrm{M}$ compared with the surface layer of L (Kruskal-Wallis, $P=0.007$ ).
The algal carbon concentrations at the three zones showed similar fluctuations during the sampling period (Table 2).

The highest turbidity values were recorded in the middle and edge of macrophytes (ANOVA, $F=7.4$, $P=0.004)$ compared with zone $\mathrm{L}$, only during the shortterm study (Fig. 1).

\section{Composition, size, fecundity and spatial distribution of zooplankton}

The mean densities of the cladocerans $D$. birgei and Daphnia ambigua were significantly different (Kruskal-Wallis, $P<0.05$ ) comparing the three zones, while there was no difference among the densities of C. richardi and Daphnia gessneri. D. birgei was found exclusively in $\mathrm{M}$, with few individuals in $\mathrm{E}$ and none in $\mathrm{L}$, while D. ambigua predominated in $\mathrm{L}$, with a few individuals sampled in E (Fig. 2). The DCA, using the cladoceran densities, confirmed the distribution pattern among the three zones (Fig. 3). The zone with smaller scores on DCA1, but higher on DCA2, was represented by macrophytes, which are mostly occupied by $D$. birgei. The limnetic zone, with higher scores on DCA1, and intermediate on DCA2, was preferentially occupied by

Table 1. Maximum and minimum values of physical and chemical factors in the lake during the short-term study and during the experiments with two cladocerans.

\begin{tabular}{|c|c|c|c|c|c|c|}
\hline \multirow[b]{2}{*}{ Physical and chemical factors } & \multicolumn{2}{|c|}{ Short-term study } & \multicolumn{2}{|c|}{ Experiment 1 Ceriodaphnia richardi } & \multicolumn{2}{|c|}{ Experiment 2 Diaphanosoma birgei } \\
\hline & $\overline{\text { Maximum }}$ & Minimum & Maximum & Minimum & Maximum & Minimum \\
\hline \multicolumn{7}{|c|}{ Middle of macrophyte stands (M) } \\
\hline Temperature $\left({ }^{\circ} \mathrm{C}\right)$ & 23.6 & 20.6 & 28.9 & 27.0 & 20.7 & 20.1 \\
\hline Dissolved oxygen (mg.L $\left.{ }^{-1}\right)$ & 11.4 & 9.8 & 10.4 & 4.7 & 10.5 & 9.4 \\
\hline $\mathrm{pH}$ & 7.2 & 6.0 & 7.1 & 5.0 & 6.5 & 6.2 \\
\hline \multicolumn{7}{|l|}{ Edge of macrophytes (E) } \\
\hline Temperature $\left({ }^{\circ} \mathrm{C}\right)$ & 23.5 & 20.4 & 28.8 & 27.1 & 20.8 & 20.1 \\
\hline Dissolved oxygen (mg.L $\left.{ }^{-1}\right)$ & 12.2 & 10.7 & 10.3 & 5.3 & 10.8 & 9.3 \\
\hline $\mathrm{pH}$ & 7.1 & 6.1 & 7.1 & 5.3 & 6.9 & 6.5 \\
\hline \multicolumn{7}{|l|}{ Limnetic zone (L) } \\
\hline \multicolumn{7}{|l|}{ Temperature $\left({ }^{\circ} \mathrm{C}\right)$} \\
\hline Surface & 23.3 & 20.2 & 28.6 & 27.1 & 20.7 & 20.1 \\
\hline Bottom & 19.7 & 19 & 27.4 & 26.9 & 20.4 & 19.7 \\
\hline \multicolumn{7}{|l|}{ Dissolved oxygen (mg.L ${ }^{-1}$ ) } \\
\hline Surface & 14.6 & 12 & 12.6 & 5.8 & 11.4 & 9.33 \\
\hline Bottom & 6.9 & 0.8 & 8.7 & 2.1 & 8.8 & 8.0 \\
\hline \multicolumn{7}{|l|}{$\mathrm{pH}$} \\
\hline Surface & 6.5 & 5.1 & 7.1 & 5.6 & 7.0 & 6.4 \\
\hline Bottom & 6.7 & 5.4 & 6.4 & 5.0 & 5.6 & 3.5 \\
\hline
\end{tabular}

Table 2. Mean $( \pm \mathrm{SE})$ algal carbon concentrations in the three zones of the lake during the short-term study and during the experiments with two cladocerans.

\begin{tabular}{lccc}
\hline & \multicolumn{2}{c}{ Algal carbon concentration (mg C.L ${ }^{-\mathrm{I}}$ ) } \\
\cline { 2 - 4 } Zones & Short-term study & Experiment 1 Ceriodaphnia richardi & Experiment 2 Diaphanosoma birgei \\
\hline M (macrophytes) & $1.21 \pm 0.18$ & $0.88 \pm 0.14$ & $0.98 \pm 0.01$ \\
E (edge of macrophytes) & $1.21 \pm 0.19$ & $0.82 \pm 0.12$ & $0.97 \pm 0.06$ \\
L (limnetic zone) & $1.26 \pm 0.18$ & $1.18 \pm 0.05$ & $0.92 \pm 0.07$ \\
& Ns & Ns & Ns \\
\hline
\end{tabular}



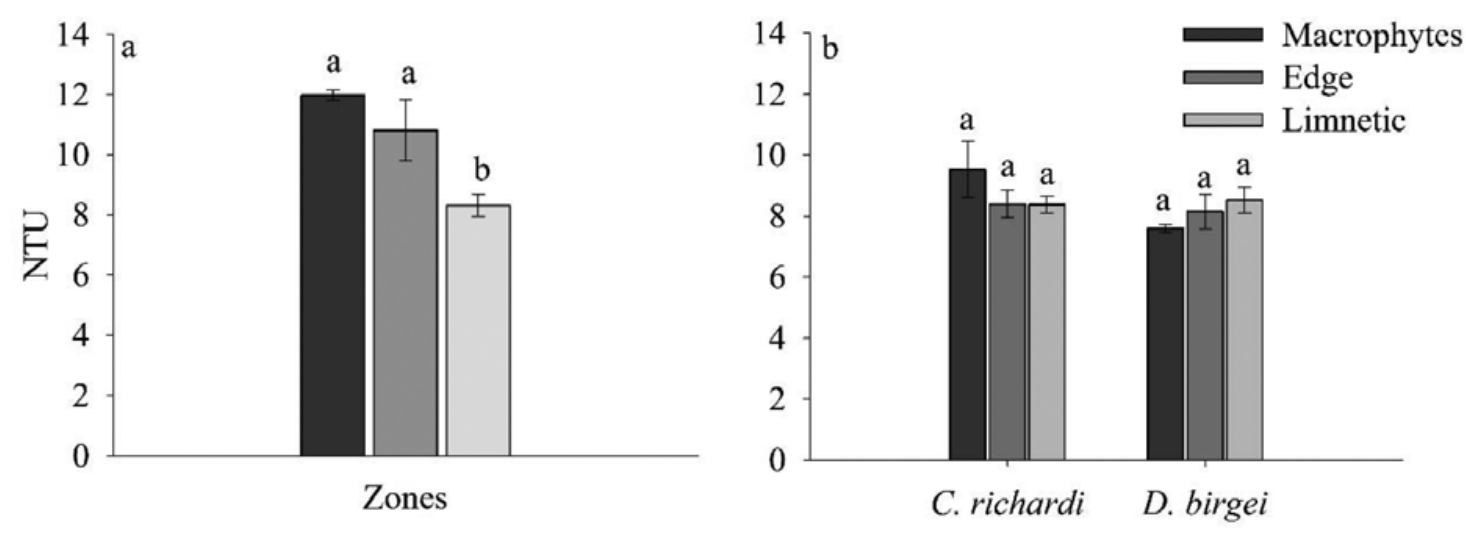

Fig. 1. Mean $( \pm S E)$ turbidity values during the short-term study and experiments with two cladocerans. Different letters indicate significant differences $(P<0.05)$.
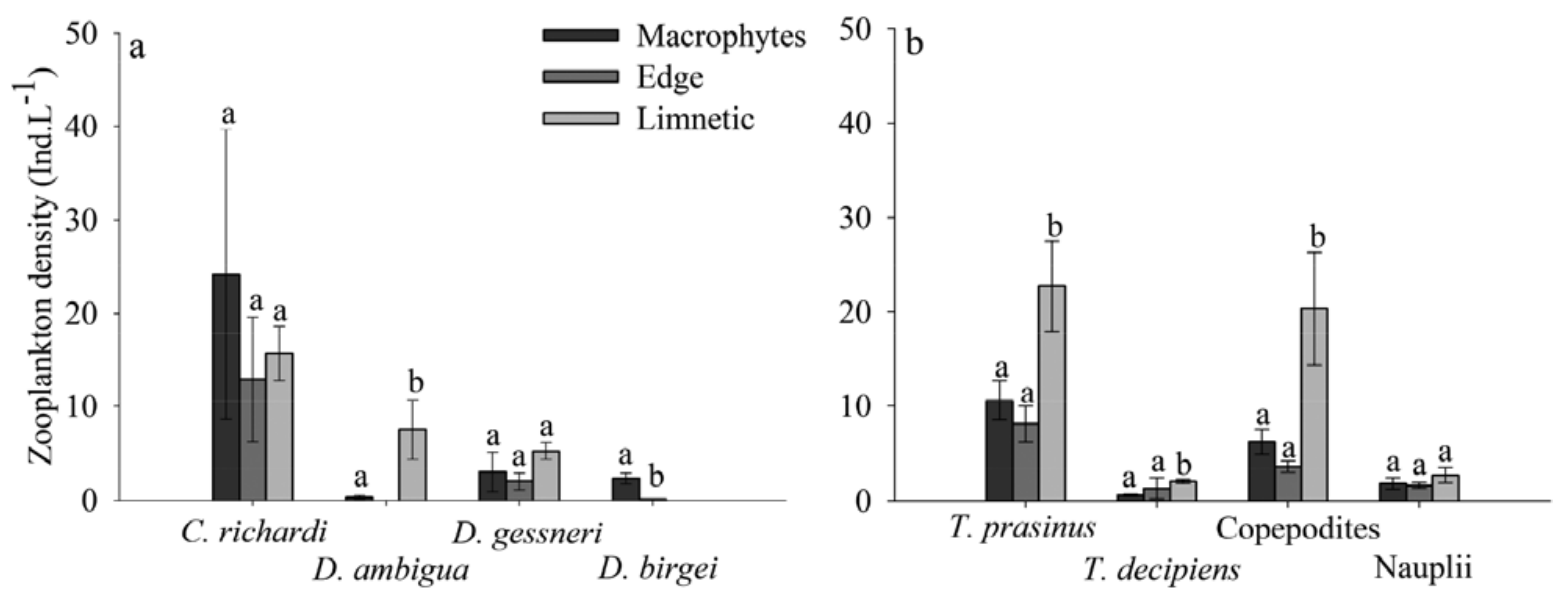

Fig. 2. Mean densities $( \pm \mathrm{SE})$ of cladocerans and copepods at three zones in the lake during the short-term study. Different letters indicate statistical difference $(P<0.05)$.
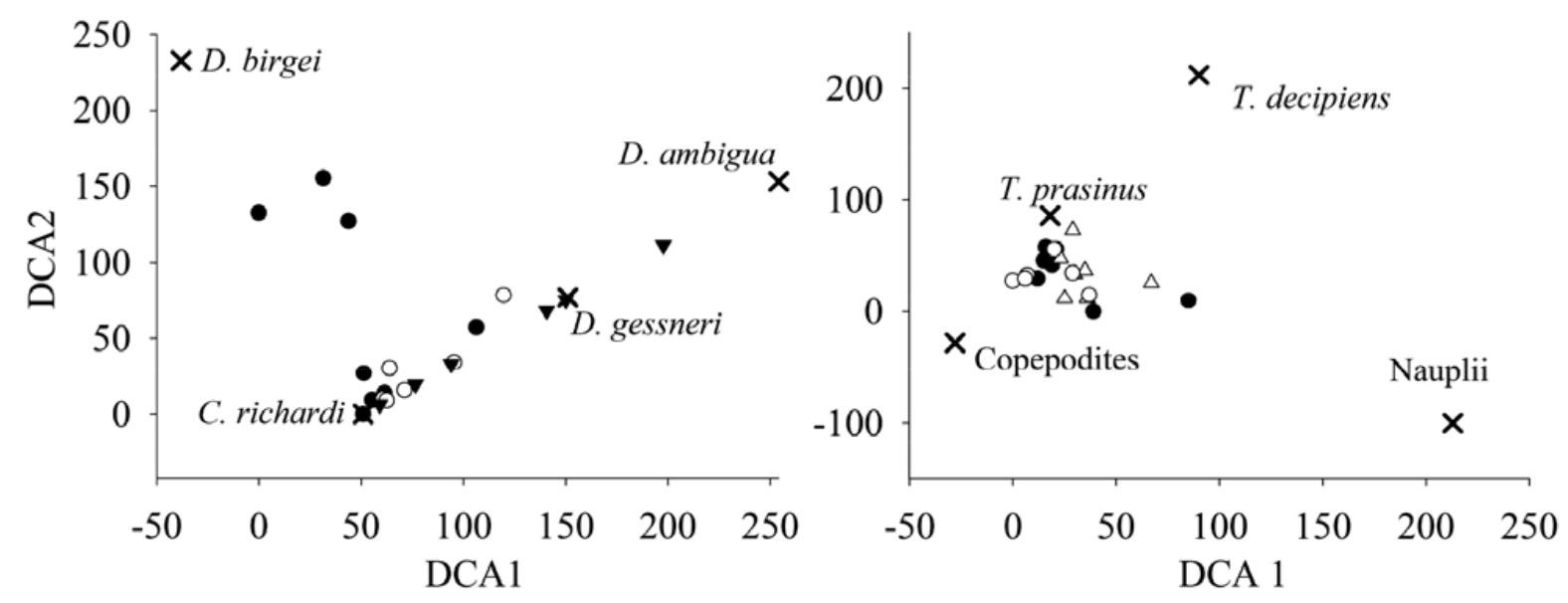

- Macrophytes $\bigcirc$ Edge $\boldsymbol{~ L i m n e t i c ~}$

Fig. 3. Detrended correspondence analysis (DCA) of cladocerans (left panel) and copepods (right panel) at three zones of the lake, during the short-term study. 
Table 3. Average within-group distance, summary statistics for Multi-Response Permutation Procedures (MRPP), comparison between the pairs of zones presented by the Multi-Response Permutation Procedures (MRPP) comparing all groups, and pairwise comparison for the Sorensen (Bray-Curtis) distances.

\begin{tabular}{|c|c|c|c|c|c|c|c|}
\hline \multicolumn{8}{|c|}{ Average within-group distance } \\
\hline \multicolumn{8}{|c|}{ Summary statistics for MRPP } \\
\hline Sorensen distances & 0.562 & 0.639 & 0.489 & -1.15 & -3.48 & 0.12 & $0.006^{*}$ \\
\hline \multicolumn{8}{|c|}{ Multiple comparisons (Sorensen-Bray Curtis) } \\
\hline Edge vs limnetic & & & & & -3.875 & 0.155 & $0.005^{*}$ \\
\hline
\end{tabular}

$T$ refers to statistic $t$, as a separation measure; A indicates the chance-corrected within-group agreement; and $P$ values indicate the significance. *indicates significant differences $(P<0.05)$.

D. ambigua. Axis 1 presented an eigenvalue $=0.41$ and the groups proposed presented significant differences in MRPP $(A=0.12, P=0.006)$ (Table 3$)$.

Except nauplii, higher densities of other copepod stages occurred in L (Fig. 2). Mean densities of copepodites (Kruskal-Wallis, $P=0.007$ ) and adult Tropocyclops prasinus and Thermocyclops decipiens (Kruskal-Wallis, $P=0.01$ for both) were higher in $\mathrm{L}$ than in $\mathrm{M}$ and $\mathrm{E}$. The DCA for copepod stages did not show conclusive results (axis 1 , eigenvalue $=0.08$ ) that may reflect the great density variation during the sampling period (Fig. 3).

It was possible to perform statistical analysis only in relation to the body size of $C$. richardi, D. ambigua and $D$. gessneri, due to the limited number of individuals of the other species. Only the size of D. ambigua was significantly larger at both stations $\mathrm{E}$ and $\mathrm{L}$ than in M (ANOVA, $F=5.7, \quad P=0.02$ ) (Fig. 4). As the number of large ovigerous females was insufficient in the samples, the statistical analysis was performed for the clutch size of $C$. richardi, and showed that it was similar at the three zones (Fig. 4).

The main invertebrate predator, Chaoborus brasiliensis, was found only in $\mathrm{L}$, with average densities of $0.06 \pm 0.2$ and $0.04 \pm 0.1$ ind. $\mathrm{L}^{-1}$, respectively for the instars III and IV. Water mites were virtually absent during the short-term study.

\section{Experiments}

\section{Physical, chemical and biological factors}

The physical and chemical characteristics of the water did not differ significantly among the three zones during each experiment (Table 1). The surface DO concentrations of the zones were generally high and the minimum values were not low enough to impair the water quality for the cladocerans, like the $\mathrm{pH}$ values.

Values for turbidity and concentrations of the inorganic and organic suspended matter showed no significant differences among the three zones ( $\mathrm{M}, \mathrm{E}$ and $\mathrm{L}$ ), during both experiments (Fig. 1 and Fig. 5). There were no significant differences in the mean concentrations of algal
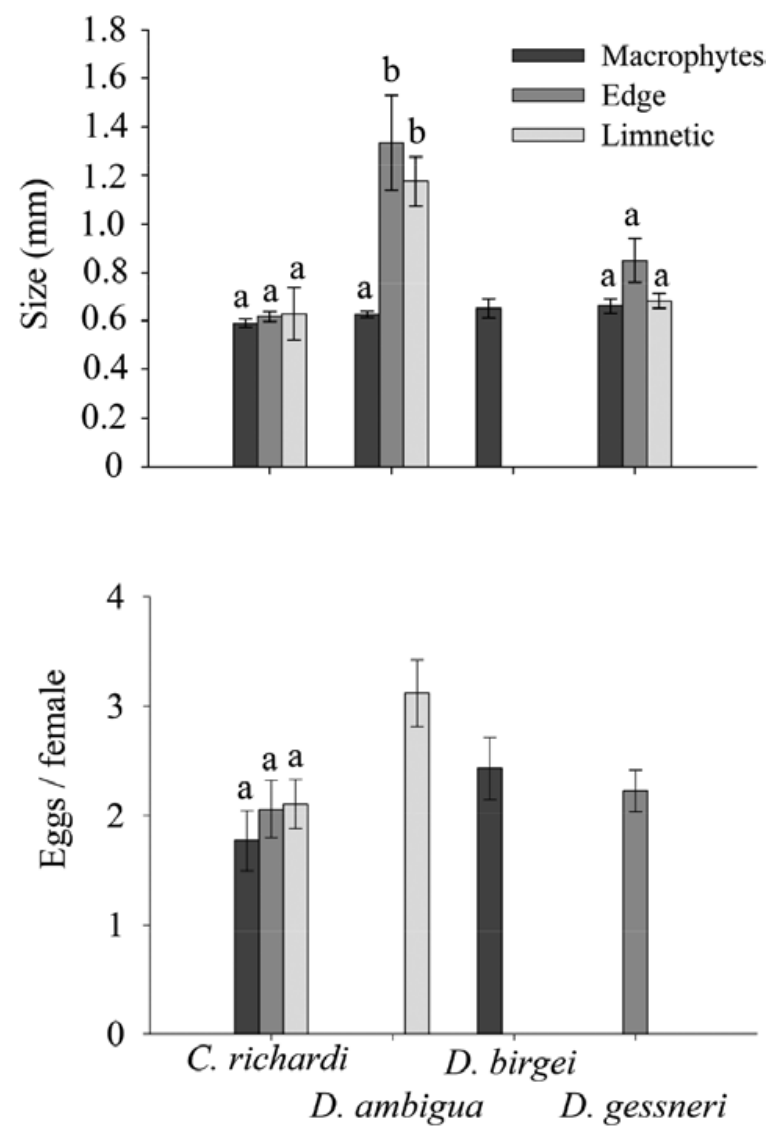

Fig. 4. Mean size and eggs per female $( \pm \mathrm{SE})$ of cladocerans during the short-term study. Different letters indicate significant differences $(P<0.05)$.

carbon among the three zones, in both experiments (Table 2).

The phytoplankton was numerically dominated by chlorophyceans, cyanobacteria and zygnematophyceans during experiment I, with $C$. richardi, whereas in experiment II, with $D$. birgei, chlorophyceans, cyanobacteria and chrysophyceans predominated (Fig. 6).

The nanoplankton fraction $(\leq 20 \mu \mathrm{m})$ predominated at the three zones, in both experiments. The percentage contribution of the nanoplankton fraction during the 

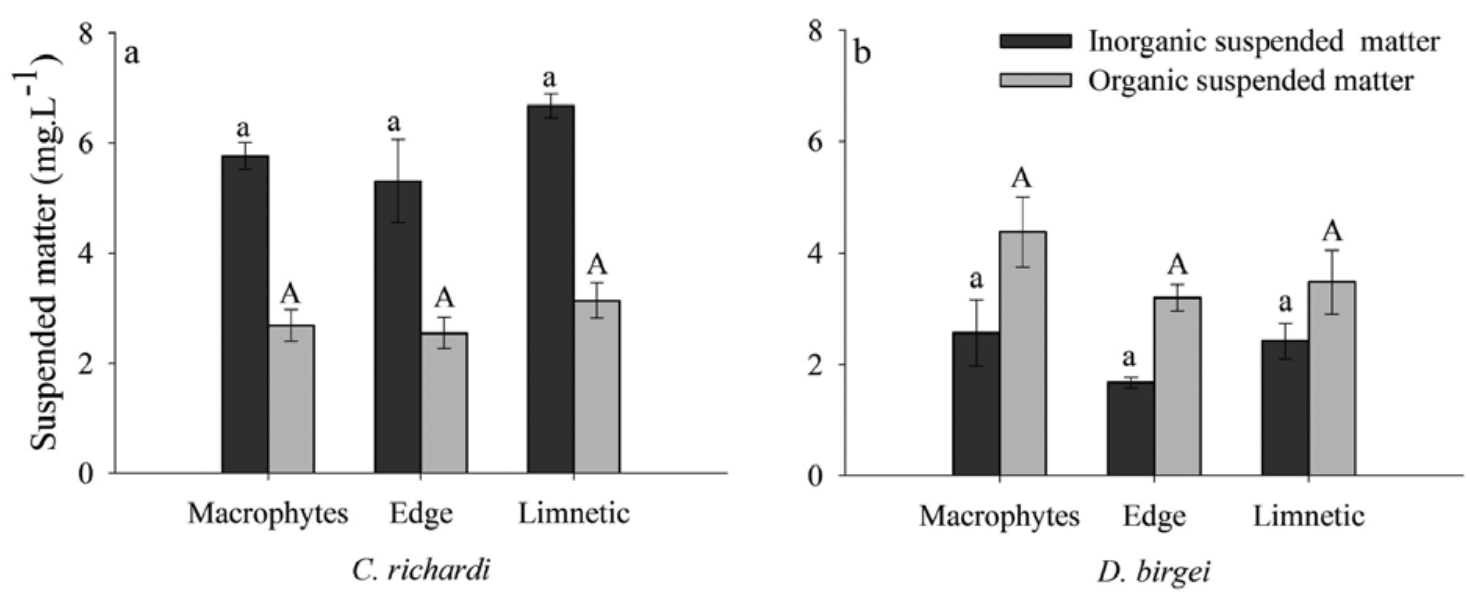

Fig. 5. Mean concentrations $( \pm S E)$ of organic and inorganic suspended matter during the experiments with two cladocerans. Different letters indicate significant differences $(P<0.05)$.
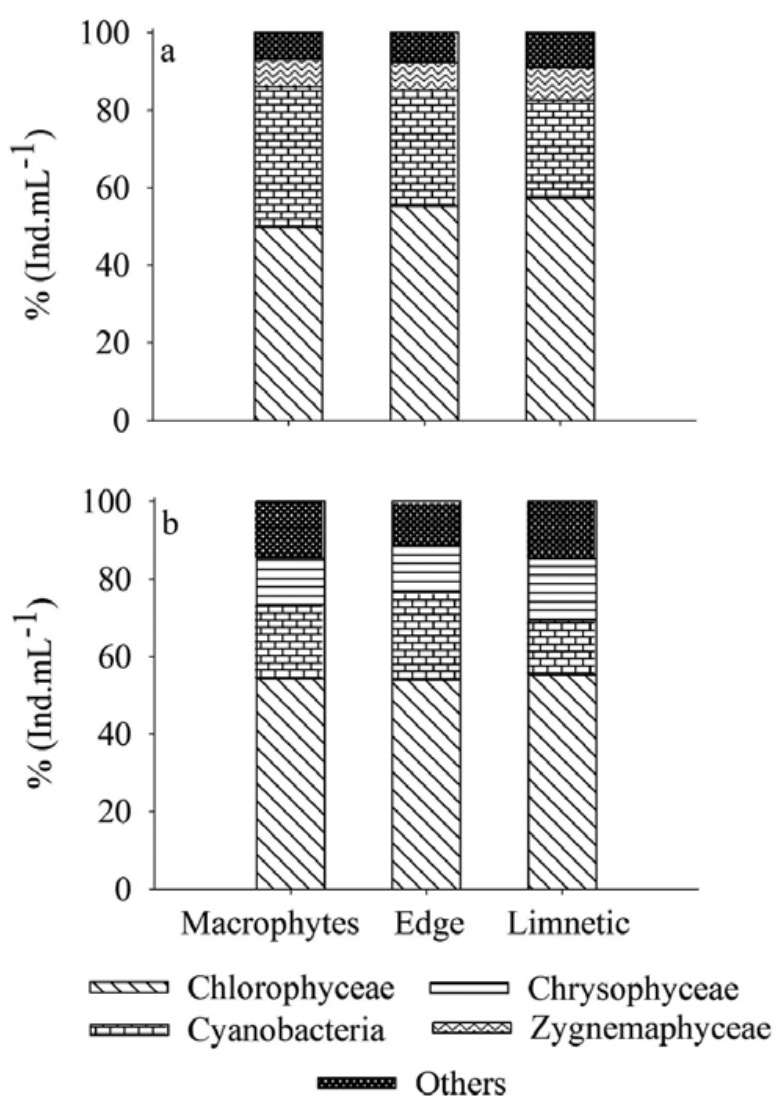

Fig. 6. Relative abundance of the most abundant groups of phytoplankton during experiments with seston of three zones in the lake. $a=C$. richardi experiment, $b=D$. birgei experiment.

experiments were $74.6(\mathrm{M}), 68.8(\mathrm{E})$ and $64.8(\mathrm{~L})$, during the experiment I, and $69.7(\mathrm{M}), 69.3(\mathrm{E})$ and $67.0(\mathrm{~L})$, during experiment II.

\section{Intrinsic growth rate $(r)$ and life table parameters}

The intrinsic growth rate $(r)$ of $C$. richardi was significantly higher with the seston of M (ANOVA,
$F=19.41, \quad P<0.001)$ (Table 4). Similarly, the highest rates of $D$. birgei were recorded with the seston of $\mathrm{M}$ and in the treatment with the chlorophycean D. spinosus (Kruskal-Wallis, $P<0.01$ ).

There were no significant differences among treatments for any of the life table parameters for C. richardi (Table 4). On the contrary, D. birgei showed significant differences of the total number of neonates per female, mean fecundity and maximum neonates per clutch (Kruskal-Wallis, $P<0.05$ ). Except for the fecundity, the other two parameters indicated that the seston of $\mathrm{M}$ allowed better reproductive performance of $D$. birgei, similarly to the treatment with the chlorophycean.

\section{Discussion}

Five out of eight microcrustaceans showed preference for habitat in Lake Monte Alegre. While the cladoceran $D$. birgei preferred the littoral zone, D. ambigua and both adult copepods and copepodites distributed preferentially in the limnetic zone; $C$. richardi, D. gessneri and nauplii occupied the three zones indistinctly. Physical and chemical features were not a barrier to the displacement of the microcrustaceans among the three habitats because the conditions were similar. However, it is worth emphasizing that the macrophyte stands are narrow and do not take up large areas of the lake, i.e., this lake is not comparable with lakes and ponds with very dense and extensive macrophyte coverage.

The short-term horizontal distribution of species largely repeated the pattern presented in the study throughout the year in the lake, with monthly frequency (Arcifa et al., 2013), but when only the edge of the anchored macrophyte Eichhornia azurea was evaluated. We also observed that the densities of microcrustaceans varied at the three zones in the short interval of 3 days, indicating the exchange of individuals among them. Although D. birgei was found previously in the limnetic zone of the lake in the course of almost three decades, its 
Table 4. Mean $( \pm \mathrm{SE})$ of life table parameters and population growth rate of two cladocerans in experiments with seston of three zones in the lake.

\begin{tabular}{|c|c|c|c|c|}
\hline & $\mathrm{M}$ & $\mathrm{E}$ & $\mathrm{L}$ & Chlorophycean \\
\hline \multicolumn{5}{|l|}{ Experiment I Ceriodaphnia richardi } \\
\hline Age at first reproduction (days) & $5 \pm 0$ & $5 \pm 0$ & $5 \pm 0$ & - \\
\hline Size at first reproduction $(\mathrm{mm})$ & $0.60 \pm 0$ & $0.65 \pm 0$ & $0.60 \pm 0$ & - \\
\hline Average clutch size/female & $10 \pm 0.74$ & $8 \pm 1.18$ & $10 \pm 0.78$ & - \\
\hline Total neonates/female & $90 \pm 10$ & $78 \pm 13$ & $82 \pm 8$ & - \\
\hline Average fecundity & $8.76 \pm 0.5$ & $8.40 \pm 0.4$ & $8.10 \pm 0.2$ & - \\
\hline Maximum of neonates/clutch & $11 \pm 0.63$ & $10 \pm 0.65$ & $10 \pm 0.51$ & - \\
\hline Generation time $(G)$ & $14.3 \pm 0.61$ & $13.0 \pm 0.84$ & $15.4 \pm 0.5$ & - \\
\hline Intrinsic population growth rate $(r)$ & $0.49 \pm 0.005(\mathrm{a})$ & $0.44 \pm 0.002(b)$ & $0.45 \pm 0.005(b)$ & - \\
\hline \multicolumn{5}{|l|}{ Experiment II Diaphanosoma birgei } \\
\hline Age at first reproduction (days) & $4.3 \pm 0.2$ & $4.6 \pm 0.1$ & $4.7 \pm 0.2$ & $4.2 \pm 0.1$ \\
\hline Size at first reproduction (mm) & $0.88 \pm 0.005$ & $0.84 \pm 0.02$ & $0.88 \pm 0.03$ & $0.90 \pm 0.005$ \\
\hline Average clutch size/female & $6.0 \pm 0.7$ & $5.0 \pm 0.9$ & $5.0 \pm 0.6$ & $5.4 \pm 0.7$ \\
\hline Total neonates/female & $34 \pm 3.9$ (a) & $27 \pm 5.0(\mathrm{~b})$ & $30 \pm 3.6(b)$ & $50 \pm 6.7$ (a) \\
\hline Average fecundity & $5.9 \pm 0.2(b)$ & $5.2 \pm 0.2(\mathrm{~b})$ & $5.7 \pm 0.2(\mathrm{~b})$ & $9.1 \pm 0.4(\mathrm{a})$ \\
\hline Maximum of neonates/clutch & $7.0 \pm 0.2(b)$ & $5.7 \pm 0.4(\mathrm{c})$ & $6.5 \pm 0.3(\mathrm{c})$ & $11.0 \pm 0.6(a)$ \\
\hline Generation time $(G)$ & $8.79 \pm 0.55$ & $8.90 \pm 0.9$ & $9.10 \pm 0.65$ & $8.22 \pm 0.47$ \\
\hline Intrinsic population growth rate $(r)$ & $0.62 \pm 0.02(\mathrm{ab})$ & $0.56 \pm 0.02(\mathrm{~b})$ & $0.57 \pm 0.04(\mathrm{~b})$ & $0.70 \pm 0.01(\mathrm{a})$ \\
\hline
\end{tabular}

Average fecundity (number of neonates produced per clutch/total females), $r$ (mean \pm SE day -1 ). Different letters indicate significant differences; values in decreasing order $\mathrm{a}>\mathrm{b}>\mathrm{c}(P<0.05)$.

relative contribution was generally low, except in 1998-1999, when a mite, a second limnetic predator, was detected in the lake, changing the zooplanktonic structure (Arcifa et al., 2015).

We may question, then, the adaptive strategy of the occupation of the lake areas by populations of planktonic microcrustaceans. A possibility is to decrease predation risk, even temporarily. The dietary conditions and physical and chemical factors allow their full development even outside the limnetic zone. Specific food components, other than algae, may be the main reason for occupying a particular zone.

In relation to predation, we have data from other studies in the lake over 30 years. The occupation of the littoral zone, where the crustaceans spend more than 1 day, may be an adaptive behaviour of some species to decrease the predation risk by limnetic invertebrate predators. Although the littoral zone hosts other predators, such as notonectids and gerrids (Domingos and Arcifa, 2016, 2017), amongst others, the predation pressure by invertebrates on microcrustaceans is more intense in the limnetic zone (Arcifa et al., 2016). Our data support the possibility of higher predation pressure in the limnetic zone due to the greater abundance of chaoborids in this zone, and the knowledge that they are the predators with larger influence on crustacean plankton (Arcifa et al., 2015).

However, macrophyte stands as a daily refuge for planktonic microcrustaceans, expressed by DHM, has become questionable in shallow tropical lakes (review by Arcifa et al., 2016 and supplementary Table S1). Whilst in temperate lakes macrophytes play a decisive role as a daily refuge for prey to decrease predation risk by limnetic predators (e.g., Burks et al., 2002), in warm shallow lakes this role is less prominent. Artificial submerged macrophytes harboured more cladocerans than the freefloating ones in both temperate and subtropical lakes (Meerhoff et al., 2007). However, several studies in warm shallow lakes show that macrophytes can be avoided by microcrustaceans, including the submerged ones, due mostly to predation (Meerhoff et al., 2006; Fantin-Cruz et al., 2008; González Sagrario and Balseiro, 2010; Tavş anoğlu et al., 2012, 2015).

Regarding food, our data from the experiments with two cladocerans do not support the hypothesis that the food quantity and quality may negatively influence the microcrustaceans at the littoral habitats, in both the middle and edge of macrophyte stands. Our results agree with Booker and Cheruvelil (2011), who report no nutritional cost for the pelagic zooplankton inhabiting the littoral zone, since the amount of food was not influenced by the presence of macrophytes and the food quality was high. Our results do not agree with Smiley and Tessier (1998), who reported a lower quality of the littoral food.

Nanoplankton is more suitable for smaller species and microplankton for a large littoral species in the lake (Fileto et al., 2004). These results support the conclusion of our study that the seston was edible for the mediumsized cladocerans, during the experiments. Greater relative numerical predominance of chlorophyceans and the nanoplankton fraction at the lake zones agrees with previous results reported for the limnetic zone (Fileto, 2001).

Other features, such as higher turbidity values in the middle and edge of the macrophyte stands, in the shortterm study, demonstrate that this factor varies over space and may indicate that resuspension differs among the three zones. Nevertheless, there are indications that turbidity values and inorganic and organic suspended matter 
concentrations recorded during our experiments were not high enough to cause negative effects on cladocerans. Turbidity values between 10 and 30 NTU were responsible for the decrease of the fertility and survival of cladocerans, and concentrations of suspended matter between 100 and $2000 \mathrm{mg} . \mathrm{L}^{-1}$ can lead populations of cladocerans to death (McCabe and O'Brien, 1983). To affect cladocerans, important features of suspended matter are the concentration and particle size and quantity and quality of the phytoplankton in the environment (Kirk and Gilbert, 1990).

The indifferent occupation of the three zones by C. richardi should be adaptive to the maintenance of the population, since food is adequate. Predation of C. richardi by Chaoborus larvae was confirmed through laboratory experiments (Ferreira et al., submitted) and in mesocosms (Perticarrari, 2005). All stages of C. richardi are preyed on by Chaoborus larvae (Ferreira et al., submitted), whereas they selectively prey on juveniles of larger species, such as Daphnia (Arcifa, 2000; CastilhoNoll and Arcifa, 2007). This fact may indicate that the C. richardi population may be more strongly impacted by predation. Therefore, the advantage of also occupying the littoral zone seems to be real, prompted by the adequate food.

Since the seston of the middle of macrophyte stands was as suitable as the edible alga of the treatment with chlorophycean, $D$. birgei seems to benefit from other food components in the littoral zone. Representatives of the genus Diaphanosoma (e.g., D. excisum) feed on very small particles of 2-4 $\mathrm{m}$ (e.g., Monoraphidium, Chlorella) (Pagano, 2008). Bacteria, even though difficult to digest (Bouvy et al., 2006), are considered an important dietary component of species of Diaphanosoma and Daphnia (Hessen, 1990), playing a significant role as a food item (Wylie and Currie, 1991). The high concentration of bacterioplankton and other food sources such as protozoans and fungi due to the amount of organic detritus in the littoral zone (Peixoto et al., 2008) may explain the success of $D$. birgei in the middle of the macrophyte stands. Because D. birgei also grew well with the limnetic seston, the fact that this species was not found in the limnetic zone may be related to a greater abundance of pelagic predators, mainly Chaoborus larvae, which feed on microcrustaceans (Arcifa, 2000; Castilho-Noll and Arcifa, 2007), including all stages of D. birgei (TCS Ferreira et al. unpublished data). Species of Diaphanosoma are known as thermophilic that adapt to higher temperatures and prefer warmer areas (Lazareva, 2012; Choi et al., 2015), but the lack of temperature difference between the littoral and limnetic zones of the lake does not support this hypothesis.

In conclusion, in this shallow tropical lake, with narrow stands of emergent macrophytes in the littoral zone, planktonic microcrustaceans occupy this area, apparently without suffering negative effects. Unexpectedly, the middle of the stands of a rooted-emergent macrophyte with thick stems, such as Ludwigia sp., can also serve as a habitat for planktonic species, not differing from the edge of the stands. Nevertheless, the limnetic zone seems to be a more appropriate habitat than the littoral zone for most microcrustaceans, particularly copepods. Since the abiotic characteristics and food conditions are not negative aspects for the distribution of microcrustaceans at both zones, the possible explanations are that the depth and the hydrodynamics of the limnetic zone would be more suitable for planktonic species, regarding swimming aspects and vertical displacements.

\section{References}

Arcifa M.S., 2000. Feeding habits of Chaoboridae larvae in a tropical Brazilian reservoir. Braz. J. Biol., 60, 591-597.

Arcifa M.S. and Meschiatti A.J., 1993. Distribution and feeding ecology of fishes in a Brazilian reservoir: Lake Monte Alegre. Interciencia, 18, 302-312.

Arcifa M.S. and Meschiatti A.J., 1996. Tilapia rendalli in the Lake Monte Alegre, a case of planktivory. Acta Limnol. Brasil., 8, 221-229.

Arcifa M.S., Meschiatti A.J. and Gomes E.A.T., 1990. Thermal regime and stability of a tropical shallow reservoir: Lake Monte Alegre, Brazil. Rev. Hydrobiol. Trop., 23, 271-281.

Arcifa M.S., Gomes E.A.T. and Meschiatti A.J., 1992. Composition and fluctuations of the zooplankton of a tropical Brazilian reservoir. Arch. Hydrobiol., 123, 479-495.

Arcifa M.S., Bunioto T.C., Perticarrari A. and Minto W.J., 2013. Diel horizontal distribution of microcrustaceans and predators along a year in a shallow Neotropical lake. Braz. J. Biol., 73, 103-114.

Arcifa M.S., Ferreira T.C.S., Fileto C., Castilho-Noll M.S.M., Bunioto T.C. and Minto W.J., 2015. A long-term study on crustacean plankton of a shallow tropical lake: the role of invertebrate predation. J. Limnol., 74, 606-617.

Arcifa M.S., Perticarrari A., Bunioto T.C., Domingos A.R. and Minto W.J., 2016. Microcrustaceans and predators: diel migration in a tropical lake and comparison with shallow warm lakes. Limnetica, 35, 281-296.

Booker J. and Cheruvelil K.S., 2011. Are zooplankton food resources poor in the vegetated littoral zone of shallow lakes? Freshwat. Biol., 56, 2459-2472.

Bouvy M., Pagano M., M'Boup M., Got P. and Trousselier M., 2006. Functional strutucture of microbial food web in Senegal River Estuary (West Africa): impact of metazooplankton. J. Plankton. Res., 28, 195-207.

Bozelli R.L., 1998. Influences of suspended inorganic matter on carbon ingestion and incorporation rates of two tropical cladocerans, Diaphanosoma birgei and Moina minuta. Arch. Hydrobiol., 142, 451-465.

Burks R.L., Lodge D.M., Jeppesen E. and Lauridsen T.L., 2002. Diel horizontal migration: costs and benefits of inhabiting the littoral. Freshwat. Biol., 47, 343-365.

Carpenter S.R. and Lodge D.M., 1986. Effects of submersed macrophytes on ecosystem processes. Aquat. Bot., 26, 341-370.

Cassano C.R., Castilho-Noll M.S.M. and Arcifa M.S., 2002. Water mite predation on zooplankton of a tropical lake. Braz. J. Biol., 62, 565-571.

Castilho-Noll M.S.M. and Arcifa M.S., 2007. Chaoborus diet in a tropical lake and predation of microcrustaceans in laboratory experiments. Acta Limnol. Bras., 19, 163-174. 
Choi J.Y., Jeong K.S., La G.H. and Joo G.J., 2015. Spatiotemporal distribution of Diaphanosoma brachyurum (Cladocera: Sididae) in freshwater reservoir ecosystems: importance of maximum water depth and macrophyte beds for avoidance of fish predation. J. Limnol., 74, 403-413.

Domingos A.R. and Arcifa M.S., 2016. Spatial and temporal distribution of gerrid (Heteroptera) and predation on microcrustaceans from a tropical shallow lake. Braz. J. Biol., doi: 10.1590/1519-6984.12715.

Domingos A.R. and Arcifa M.S., 2017. Distribution and fluctuations of backswimmers (Notonectidae) in a tropical shallow lake and predation on microcrustaceans. Braz. J. Biol., 77, 108-117.

Fantin-Cruz I., Tondato K.K., Penha J.M.F., Mateus L.A.F., Girard P. and Fantin-Cruz R., 2008. Influence of fish abundance and macrophyte cover on microcrustacean density in temporary lagoons of the Northern PantanalBrazil. Acta Limnol. Brasil., 20, 339-344.

Ferrão-Filho A.S. and Arcifa M.S., 2006. Growth responses of tropical cladocerans to seston from Lake Monte Alegre (Brazil) supplemented with phosphorus, fatty acids, a green algae and a cyanobacterium. Hydrobiologia, 563, $155-165$.

Ferrão-Filho A.S., Arcifa M.S. and Fileto C., 2003. Resource limitation and food quality for cladocerans in a tropical Brazilian lake. Hydrobiologia, 491, 201-210.

Ferrão-Filho A.S., Arcifa M.S. and Fileto C., 2005. Influence of seasonal variation of seston on growth of tropical cladocerans. Braz. J. Biol., 65, 77-89.

Fileto C., 2001. O zooplâncton do Lago Monte Alegre: variação temporal e a influência das frações do fitoplâncton sobre o crescimento e reprodução de cladóceros. MSc Thesis, Universidade de São Paulo, Brazil, Ribeirão Preto.

Fileto C., Arcifa M.S., Ferrão-Filho A.S. and Silva L.H.S., 2004. Influence of phytoplankton fractions on growth and reproduction of tropical cladocerans. Aquat. Ecol., 38, 503-514.

Fileto C., Arcifa M.S., Marchetti J.M., Turati I.C. and Lopes N.P., 2007. Influence of biochemical, mineral and morphological features of natural food on tropical cladocerans. Aquat. Ecol., 41, 557-568.

González Sagrario M.A., Balseiro E., Ituarte R. and Spivak E., 2009. Macrophytes as refuge or risky area for zooplankton: a balance set by littoral predacious macroinvertebrates. Freshwat. Biol., 54, 1042-1053.

González Sagrario M.A. and Balseiro E., 2010. The role of macrophytes and fish in regulating the provision by macrophytes of refugia for zooplankton in a warm temperate lake. Freshwat. Biol., 55, 2153-2166.

Gopal B. and Goel U., 1993. Competition and allelopathy in aquatic plant communities. Bot. Rev., 59, 155-210.

Gotelli N.J., 2009. Crescimento populacional estruturado. In: Gotelli N.J. (ed.) Ecologia (4th edn), Londrina, Paraná, $50-81$.

Hart D.R., Stone L. and Berman T., 2000. Seasonal dynamics of the Lake Kinneret food web: the importance of the microbial loop. Limnol. Oceanogr., 45, 350-361.

Hessen D.O., 1990. Niche overlap between herbivorous cladocerans: the role of food quality and habitat homogeneity. Hydrobiologia, 190, 61-78.

Hessen D.O., Andersen T. and Lyche A., 1990. Carbon metabolism in a humic lake: pool sizes and cycling through zooplankton. Limnol. Oceanogr., 35, 84-99.
Horppila J. and Nurminen L., 2005. Effects of calculation procedure and sampling site on trap method estimates of sediment resuspension in a shallow lake. Sedimentology, 52, 903-913.

Jeffrey S.W. and Humphrey G.F., 1975. New spectrophotometric equations for determining chlorophylls $a, b, c_{1}$, and $c_{2}$ in higher plants, algae and natural phytoplankton. Biochem. Physiol. Pflanz., 167, 191-194.

Kirk K.L., 1991. Inorganic particles alter competition in grazing plankton: the role of selective feeding. Ecology, 72, 915-923.

Kirk K.L. and Gilbert J.J., 1990. Suspended clay and the population dynamics of planktonic rotifers and cladocerans. Ecology, 71, 1741-1755.

Kirk K.L. and Gilbert J.J., 1992. Variation in herbivore response to chemical defenses: zooplankton foraging on toxic cyanobacteria. Ecology, 73, 2208-2217.

Lazareva V.I., 2012. The distribution of species of genus Diaphanosoma (Crustacea, Cladocera) in reservoirs of Volga and Sheksna Rivers: impact of environmental factors. Inland Water Biol., 5, 257-265.

McCabe G.D. and O'Brien W.J., 1983. The effects of suspended silt on feeding and reproduction of Daphnia pulex. Am. Midl. Nat., 110, 324-337.

McCune B., Grace J.B. and Urban D.L., 2002. Analysis of Ecological Communities, MjM Software Design, Gleneden Beach.

Meerhoff M., Fosalba C., Bruzzone C., Mazzeo N., Noordoven W. and Jeppesen E., 2006. An experimental study of habitat choice by Daphnia: plants signal danger more than refuge in subtropical lakes. Freshwat. Biol., 51, 1320-1330.

Meerhoff M., Iglesias C., Teixeira-de Mello F., Clemente J.M., Jensen E., Lauridsen T.L. and Jeppesen E., 2007. Effects of habitat complexity on community structure and predator avoidance behaviour of littoral zooplankton in temperate versus subtropical shallow lakes. Freshwat. Biol., 52, 1009-1021.

Meschiatti A.J. and Arcifa M.S., 2002. Early life stages of fish and the relationships with zooplankton in a tropical Brazilian reservoir: Lake Monte Alegre. Braz. J. Biol., 62, 41-50.

Mulderij G., Mooij W.M., Smolders A.J.P. and Van Donk E., 2005. Allelopathic inhibition of phytoplankton by exudates from Stratiotes aloides. Aquat. Bot., 82, 284-296.

Mulderij G., Van Nes E.H. and Van Donk E., 2007. Macrophyte-phytoplankton interactions: the relative importance of allelopathy versus other factors. Ecol. Model, 204, 85-92.

Pagano M., 2008. Feeding of tropical cladocerans (Moina micrura, Diaphanosoma excisum) and rotifer (Brachionus calyciflorus) on natural phytoplankton: effect of phytoplankton size-structure. J. Plankton Res., 30, 401-414.

Peixoto R.S., Sá C.E.M., Guimarães A.S. and Maia-Barbosa P.M., 2008. Seasonal fluctuations of the microcrustacean assemblages in the littoral zone of Lake Dom Helvécio (Parque Estadual do Rio DOce, MG). Acta Limnol. Bras., 20, 213-219.

Perticarrari A., 2005. Distribuição espacial e interação entre presas e predadores invertebrados no lago Monte Alegre. $\mathrm{PhD}$ thesis, Universidade de São Paulo, Ribeirão Preto, Brazil.

Reynolds C.S., 1984. The Ecology of Freshwater Phytoplankton, Cambridge University Press, Cambridge, 365 p. 
Smiley E.A. and Tessier A.J., 1998. Environmental gradients and the horizontal distribution of microcrustaceans in lakes. Freshwat. Biol., 39, 397-409.

Søndergaard M.A. and Moss B., 1998. Impact of submerged macrophytes on phytoplankton in shallow freshwater lakes. In: Jeppesen E., Søndergaard M.A., Søndergaard M.O. and Christoffersen K. (eds.), The Structuring Role of Submerged Macrophytes in Lakes, Ecological Studies, Springer-Verlag, New York, 115-132.

Stemberger R.S., 1981. A general approach to the culture of planktonic rotifers. Can. J. Fish. Aquat. Sci., 38, 721-724.

Sterner R.W., Hagemeier D.D., Smith W.L. and Smith R.F., 1993. Phytoplankton nutrient limitation and food quality for Daphnia. Limnol. Oceanogr., 28, 857-871.

Tavşanoğlu U.N., Cakiroğlu A.I., Erdoğan S., Meerhoff M., Jeppesen E. and Beklioğlu M., 2012. Sediments, not plants, offer the preferred refuge for Daphnia against fish predation in Mediterranean shallow lakes: an experimental demonstration. Freshwat. Biol., 57, 95-802.

Tavşanoğlu U.N., Brucet S., Levi E.T., Bucak T., Bezirci G., Özen A., Johansson L.S., Jeppesen E. and Beklioğlu M., 2015. Size-based diel migration of zooplankton in Mediterranean shallow lakes assessed from in situ experiments with artificial plants. Hydrobiologia, 753, 47-59.
Teixeira C. and Kutner M.B., 1962. Plankton studies in mangrove environment. I. First assessment of standing stock and ecological factors. Bol. Inst. Oceanogr., 12, 101-124.

Uehlinger V., 1964. Étude statistique des méthodes de dénombrement planctonique. Arch. Sci., 17, 121-123.

Utermöhl H., 1958. Zur Vervollkommung der quantitativen Phytoplankton-Methodik. Mitt. Int. Verein. Theor. Angew. Limnol., 9, 1-38.

Walseng B., Hessen D.O., Halvorsen G. and Schartau A.K., 2006. Major contribution from littoral crustaceans to zooplankton species richness in lakes. Limnol. Oceanogr., 51, 2600-2606.

Wojtal A., Frankiewicz P., Andziak M. and Zalewski M., 2007. The influence of invertebrate predators on Daphnia spatial distribution and survival in laboratory experiments: support for Daphnia horizontal migration in shallow lakes. Int. Rev. Hydrobiol., 92, 23-32.

Wylie J.L. and Currie D.J., 1991. The relative importance of bacteria and algae as food sources for crustacean zooplankton. Limnol. Oceanogr., 36, 708-728.

Zhang S.H., Guo L., Cao J.Y. and Shang J.J., 2015. Allelopathic activities of three emergent macrophytes on several monospecific cyanobacterial species and natural phytoplankton assemblages. Pol. J. Env. Stud., 24, 397-402. 